\title{
Post-embryonic development stages of Tityus columbianus (Thorell, 1846), (Scorpiones, Buthidae): morphometric estimation approach
}

\section{Etapas de desarrollo posembrionario de Tityus columbianus (Thorell, 1846), (Scorpiones, Buthidae): enfoque de estimación morfométrica}

\author{
Matías Gómez C. \\ Department of Biologic Sciences, Universidad de los Andes, Bogotá, D. C., Colombia
}

Eduardo Flórez

Biological Sciences Institute, Universidad Nacional de Colombia, Bogotá, D. C., Colombia

Linda Hernández

Department of Natural and Environmental Sciences. Faculty of Natural Science and Engineering, Universidad de Bogotá Jorge Tadeo Lozano, Bogotá, D. C., Colombia

Gonzalo E. Fajardo Medina

Department of Natural and Environmental Sciences. Faculty of Natural Science and Engineering, Universidad de Bogotá Jorge Tadeo Lozano, Bogotá, D. C., Colombia gonzalo.fajardo@utadeo.edu.co

Sugerencia de citación: Gómez C., M., Flórez, E., Hernández, L. y Fajardo Medina, G. E. (2017). Post-embryonic development stages of Tityus columbianus (Thorell, 1846), (Scorpiones, Buthidae): morphometric estimation approach. Mutis, 7(2), 75-80, doi: http://dx.doi.org/10.21789/22561498.1257

Editor: Hernández Fernández, J. javier.hernandez@utadeo.edu.co

\section{ABSTRACT}

Little information about Tityus columbianus (Thorell, 1846) lifecycle and molting exists. In this study, the number of post-embryonic development stages was determined by using geometric morphometric tools, and through classical equations of Pzibram \& Megusâr (1984). Analyses included image digitalization, placement of landmarks, and matrix derivation based on Euclidean distances. The analysis established that $T$. columbianus goes through about six to seven stages along its post-embryonic development.

Keywords: Scorpions, molting, landmarks, geometric morphometry, euclidean distances. 


\section{RESUMEN}

Poca información existe sobre el ciclo de vida y número de mudas por los cuales pasa el Tityus columbianus (Thorell, 1846) para alcanzar la madurez. En este studio, el número de estados de desarrollo posembriónico fue determinado usando herramientas de morfometría geométrica y por medio de las ecuaciones clásicas de Pzibram y Megusâr (1984). Los análisis incluyeron digitalización de imagenes, definición de puntos de referencia homólogos (o landmarks) y derivación de matrices basadas en distancias euclidianas. Los análisis permiten esatablecer que el T. columbianus pasa por seis o siete estados (mudas) en su desarrollo posembrionario.

Palabras clave: escorpiones, muda, puntos homólogos, morfometría geométrica, distancias euclidianas.

\section{INTRODUCTION}

Tityus columbianus is a scorpion that belongs to the Buthidae family and that is endemic of Eastern Andes of Colombia. Its populations are found between 2200 to 3000 m (Botero-Trujillo y Fagua, 2007; Bohórquez et al., 2005; Flórez, 2001; Fet y Lowe, 2000, Lourenço, 1997). As described by Teruel and García (2008), T. columbianus is a particular case of scorpion which general aspects of its biology are known. However, there are no studies focused on specific patterns of the population, such as their lifecycle; as a matter of fact, there is only one taxonomic and systematic work. It is a brownish, mottled with yellowish spots, smallsized scorpion (Fig. 2a), well-known for having sexual populations in the northernmost area of its geographic distribution (Fig.1), while to the south (Bogotá savanna and vicinity) there are parthenogenetic populations (Lourenco, 1991; Lourenco, et al., 1996). So far it has not been possible to complete the lifecycle of T. columbianus under laboratory conditions and therefore determine the number of molts to maturity. The aim of this study was to determine the number of stages involved in the lifecycle of $T$. columbianus, applying the geometric progression index established by Pzibram \& Megusâr (Francke y Sissom, 1984), which allows to infer with a high degree of reliability the number of stages based on measurement of specimens' structures of well-known ages.

\section{Materials and Methods}

\section{Study Site}

Specimens used in this study were collected near Arcabuco, Iza and Villa de Leyva towns (Fig.1) of Boyacá (Colombia) during the first semester of 2011. They were deposited in the arachnological collection of Universidad Nacional de Colombia (Bogotá). The sample consisted of 47 specimens of T. columbianus: 23 adult females -three from Arcabuco, two from Iza and 18 from Villa de Leyva-, and 24 juveniles - nine from Arcabuco, seven from Iza and eight from Villa de Leyva.

Figure 1. Location of collected samples of T. columbianus (Boyacá, Colombia)

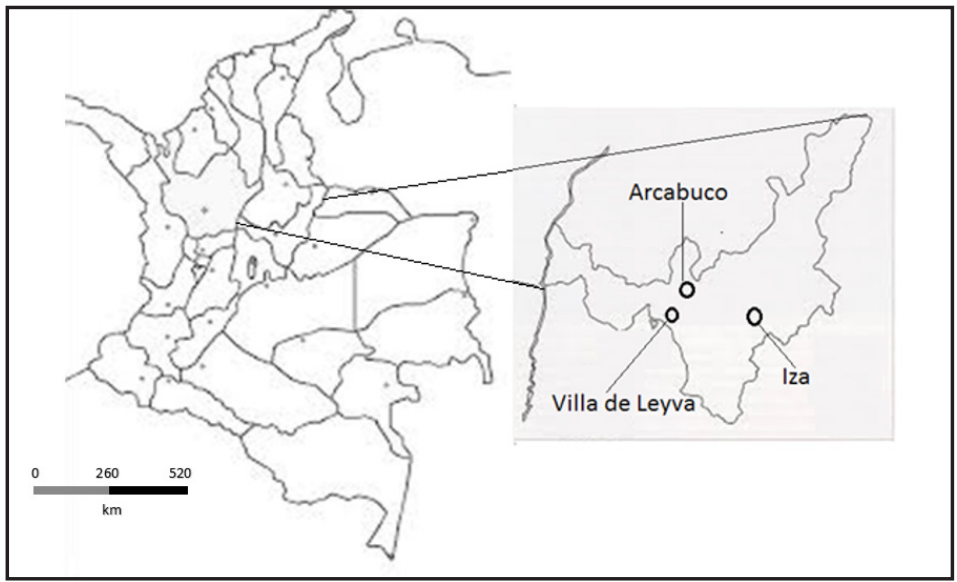




\section{Measurement of characters}

Three characters were measured: dorsal median line of carapace, pedipalp chela (left) from the base to the tip, and the left median lateral line of the fifth metasomal segment (Fig. 2). Longitudinal measures of these characters were taken using TpsDig2 geometric morphometry software (Rohlf, 2006). Specimens were photographed placing them onto millimetric paper to get a scale and a measurement conversion factor in millimeters of each chosen character (adults with Nikon Coolpix p100 and juveniles with Leica EZ4D stereomicroscope). Landmarks (Bookstein, 1991) were placed at the tip and base of the measured structure (Fig. 2), and saved in a TPS file with coordinates for each point. The reference points were standardized for second instar juveniles and adults. Several replicates of landmarks were made according to indications by Arnqvist \& Mârtensson (1998) for these studies. Through Euclidian distance calculation of each landmark point coordinates (Bookstein, 1991), and multiplying it by the conversion factor obtained with milimetric paper, the final distance in millimeters between landmarks was obtained. Matrixes of distances for each structure and their average in adults and juveniles were generated from the sample.

Figure 2. A. T. columbianus adult; B. Landmarks at the dorsal median line of carapace; C. Landmarks at fifth metasomal segment; D. Landmarks at the pedipalp chela

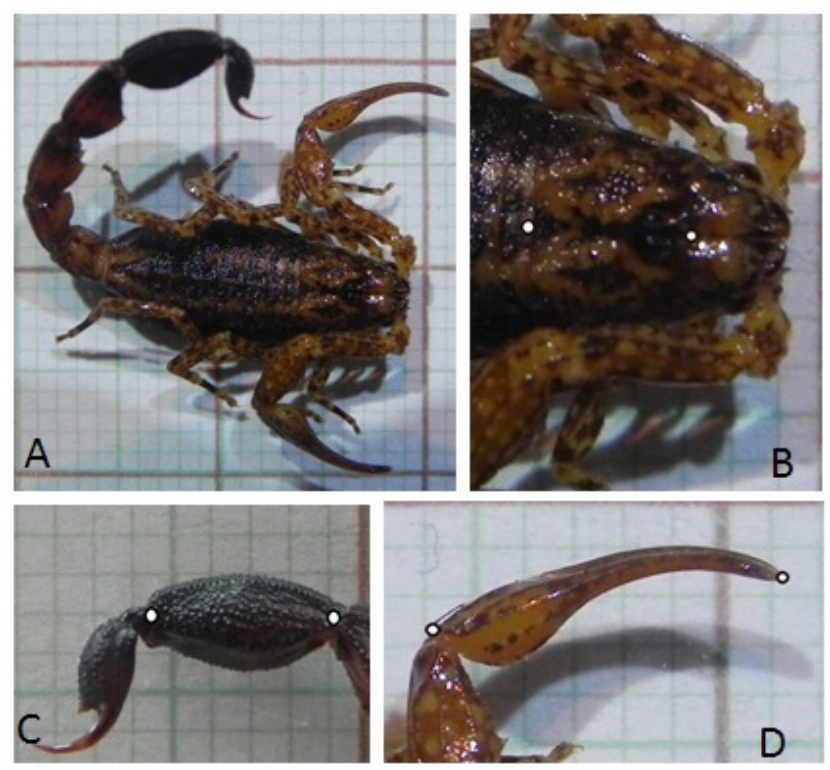

The obtained values were introduced to Francke \& Sissom (1984) prediction equation:

$$
n L=\log A-\log Y / \log P
$$

Where $n$ is the number of required stages for a juvenile to reach adult size, $A$ is the structure measure of an adult, $Y$ is the measure of the same structure in the juvenile of a known stage, and $P$ is the theoretical progression factor 1.26 (Francke y Sissom,1984). The progression factor refers to the relation between the size of a measure character from one stage to the next (Polis, 1990).

\section{RESULTS AND DISCUSSION}

In this study, the geometric progression index established by Pzibram \& Megusâr (Francke \& Sissom, 1984) was used according to their proposed theoretical method. The predictions of such method, under the assumption of a constant 1.26 progression factor, determine the number of stages involved in the lifecycle of $T$. columbianus. The theoretical method is based on the knowledge that certain measurements in successive stages of at least some arthropods increase in a regular geometrical progression. By knowing the length of some structures on newborn and adult arthropods, and assuming the progression law to be valid for that species, the number of molts (or intervening stages in the geometrical progression) linking newborn and adult measurements can be calculated (Francke \& Sissom, 1984).

Table 1 shows all measurements obtained using TpsDig2 geometric morphometry software (Rohlf, 2006), whilst table 2 shows the results obtained after carrying the base 10 logarithm of each average and the estimated stages per locality obtained by applying geometrical progression index. 
Table 1. Measurements obtained using TpsDig2 geometric morphometry software (Rohlf, 2006). Carapace, pedipalp chela, and metasomal segment $V$ of young and adults of $T$. columbianus

\begin{tabular}{|c|c|c|c|c|c|c|}
\hline \multirow[t]{2}{*}{ Loca lidad } & \multirow{2}{*}{\multicolumn{2}{|c|}{$\begin{array}{c}\text { X Carapace } \\
(m \mathrm{~m})\end{array}$}} & \multirow{2}{*}{\multicolumn{2}{|c|}{$\begin{array}{l}\text { X pedipalp chela } \\
(\mathbf{m} \mathbf{m})\end{array}$}} & \multirow{2}{*}{\multicolumn{2}{|c|}{$\begin{array}{c}\bar{X} \text { metasomal segment } V \\
(\mathrm{~m} \mathrm{~m})\end{array}$}} \\
\hline & & & & & & \\
\hline A rca buco & 3.9229 & 1.5952 & 7.1293 & 2.6675 & 4.5356 & 1.5441 \\
\hline Iz a & 4.1047 & 1.5232 & 7.5482 & 2.6910 & 4.9404 & 1.6910 \\
\hline \multirow{2}{*}{$\begin{array}{l}\text { Villade } \\
\text { Leyva }\end{array}$} & 4.0240 & 1.3467 & 7.1976 & 2.2974 & 4.6410 & 1.4940 \\
\hline & A & $Y$ & A & $\mathbf{Y}$ & A & $\mathrm{Y}$ \\
\hline
\end{tabular}

${ }^{*} \mathrm{~A}=$ adult $\mathrm{Y}=$ young

Table 2. Theoretical morphometric prediction of the number of stages $(\mathrm{n})$ for second instar juveniles of $T$. columbianus

\begin{tabular}{ccccccccc}
\hline Locality & \multicolumn{2}{c}{ Carapace Log $\overline{\mathrm{X}}$} & \multicolumn{2}{c}{ Chela Log $\overline{\mathrm{X}}$} & Fifth metasomal segment Log $\overline{\mathrm{X}}$ & Total prediction (n) \\
Arcabuco & 0.5936 & 0.2028 & 0.8530 & 0.4261 & 0.6566 & 0.1887 & 4.2853 \\
Iza & 0.6133 & 0.1827 & 0.8778 & 0.4299 & 0.6938 & 0.2281 & 4.4810 \\
Villa de Leyva & 0.6047 & 0.1293 & 0.8572 & 0.3612 & 0.6666 & 0.1743 & 4.8713 \\
A= Adult & A & Y & A & Y & A & Y & \\
Y= Juvenile & & & & & & &
\end{tabular}

Estimates per locality were obtained from averaging the values given by this index in each structure separately. These values were averaged again, getting a total estimated of 4.54 molts. This value was rounded off to the nearest integer since there is not fraction of a molt. In this study, being a theoretical approach, it was assumed that the value is between 4 and 5 stages from the second instar.

Therefore, it means that $T$. columbianus could go through 6 and 7 stages along its post- embryonic development. This result is consistent with the number of stages reported for other species of the genus, whose life cycle has been completed under laboratory conditions (Polis, 1990), confirming the validity of the progression index for this species.

This research contributes to the study of Colombian scorpions and offers a parameter of the possible postembryonic development of populations in the western zone of the Andes. On the other hand, it confirms the validity of progression indexes application, which allow its extrapolation to populations of northern South America. As show by Armas (1986) for other butids, and Teruel \& Piorno (2006), the progression indexes and the theoretical method described by Francke y Sissom (1984) are a tool to estimate the number of molts along scorpions' postembryonic 
development when it has not been possible to complete their lifecycle.

\section{CONCLUSIONS}

It was possible to extrapolate the stages of development and number of molts of $T$. columbianus. It was found that such species go through 6 and 7 stages along its postembryonic development. The application of the geometric progression index established by Pzibram \& Megusâr (Francke \& Sissom, 1984), and the use of morphometry allow to infer with a high degree of reliability- the number of stages, based on measurement of specimens' structures of well-known ages.

\section{ACKNOWLEDGEMENTS}

The authors thank morphometrics.org group for their support, Universidad Nacional de Colombia (Bogotá), Department of Biological and Environmental Sciences of Universidad Jorge Tadeo Lozano, and Francisco Quiroz for his help with the redaction, as well as the anonymous reviewers of the manuscript.

\section{REFERENCES}

Arnqvist, G. y Mârtensson, T. (1998). Measurement error in geometric morphometrics: Empirical strategies to asses and reduce its impact on measure of shape. Acta Zoological Academiae Hungaricae, 44, 82.

Bohórquez, R. M., E. C. Jiménez, H. N. Lara y Flórez. E. (2005). Fluctuación poblacional del escorpión Tityus columbianus (Thorell, 1876) (Scorpiones: Buthidae) en dos localidades de la región andina de Colombia. Pp. 122. En C. A. Toscano-Gadea (ed.), Actas. Primer Congreso Latinoamericano de Aracnología. V Encuentro de Aracnólogos del Cono Sur, Mimeográfica PESCE. Montevideo.

Bookstein, F.L. (1991). Morphometric tools for landmark data. geometry and biology. New York: Cambridge University Press.
Botero-Trujillo, R. y Fagua, G. (2007). Additions to the knowledge of the geographical distribution of some Colombian scorpions (Buthidae:

Ananteris, Rhopalurus, Tityus). Revista Ibérica de Aracnología, 14, 129-134.

De Armas, L. F. (1986). Biología y morfometría de Rhopalurus garridoi armas (Scorpiones: Buthidae). Poeyana, 333, 1-27.

Fet, V. y Lowe, G. (2000). Family Buthidae C. L. Koch, 1837. Pp. 54-286. En V. Fet, W. D. Sissom, G. Lowe y M. E. Braunwalder (eds.), Catalog of the Scorpions of the World (1758-1998), New York Entomological Society.

Flórez, E. (2001). Escorpiones de la familia Buthidae (Chelicerata: Scorpiones) de Colombia. Biota Colombiana, 2(1), 25-30.

Francke, O. y Sissom, D. (1984). Comparative review of the methods used to determine the number of molts to maturity in scorpions (Arachnida), with analysis of the post-birth development of Vaejovis coahuilae Williams (Vaejovidae). The Journal of Arachnology, 12, 1-20.

Lourenço, W. R. (1991). Parthenogenesis in the scorpion Tityus columbianus (Thorell) (Scorpiones: Buthidae). Bulletin of the British Arachnological Society, 8(9), 274-276.

Lourenço, W. R., Cuéllar, O. y Méndez de la Cruz, F. R. (1996). Variation of reproductive effort between parthenogenetic and sexual populations of the scorpion Tityus columbianus. Journal of Biogeography, 23, 681-686.

Lourenco, W. R. (1997). Synopsis de la faune de scorpions de Colombie, avec des considérations sur la systématique et la biogéographie des espéces. Revue Suisse de Zoologie, 104(1), 61-79, doi: 10.1111/j.1365-2699.1996.tb00028.x

Polis, A. (1990). Biology of scorpions. Stanford University Press. Stanford, EE. UU. pp. 198-203. 
Rohlf, F. J. (2006). TPSDig. Ver. 2.05. Stony Brook, NY: Department of Ecology and Evolution, State University of New York.

Teruel, R. y Piorno I. (2006). Desarrollo postembrionario de Heteronebo bermudezi morenoi (Armas 1973), escorpión endémico de Cuba (Scorpiones: Scorpionidae: Diplocentrinae) Boletín Sociedad Entomólogica Aragonesa, 381, 77-180.

Teruel, R y García H, L. F. (2008). Rare or poorly known scorpions from Colombia. II. Redescription of Tityus columbianus (Thorell, 1876) (Scorpiones: Buthidae). Euscorpius, 64, 1-14. 